\author{
I. E. Animitsa, N. A. Kochetova \\ Ural Federal University \\ 620002, Ekaterinburg, Mira str., 19 \\ Phone: (343) 261-74-70 \\ E-mail:irina.animitsa@urfu
}

\title{
Crystal structure and imperfection of the perovskite-like proton conductor $\mathrm{Ba}_{4} \mathrm{Ca}_{2} \mathrm{Nb}_{2} \mathrm{O}_{11}$
}

\begin{abstract}
The crystal structure complex oxide $\mathrm{Ba}_{4} \mathrm{Ca}_{2} \mathrm{Nb}_{2} \mathrm{O}_{11}$ in anhydrous and hydrated forms was studied by the method of neutron diffraction, the preferred localizations of protons were set. The hydration process with temperature variation and the partial pressure of water vapor was studied. It is established that the crystallographic non-equivalence of $\mathrm{OH}$-groups in the structure determines their different thermal stability. The quasi-chemical approach was proposed that describes the formation of proton defects in oxides with structural disordering.
\end{abstract}

Keywords: neutrongramma; quasichemical approach; high temperature proton conductors (HTPC).

(C) Animitsa I. E., Kochetova N. A., 2016

\section{Introduction}

Proton conductors are widely used as components of electrochemical devices such as gas sensors, electrolysers, fuel cell membranes, etc [1-3]. The class of high temperature proton conductors (HTPC) is presented of complex oxide compounds with perovskite structure $\mathrm{ABO}_{3}$ or derived from it. In HTPC hydrogen is not part of chemical formula, its appearance in the structure of the complex oxide is provided by the equilibrium with $\mathrm{H}_{2} \mathrm{O} / \mathrm{H}_{2}$-containing atmosphere and is described as the process of dissociative dissolution of water vapor/hydrogen [4]. Since the presence of oxygen vacancies is the main factor responsible for the appearance of proton defects, the value of the proton conductivity is determined by the complex oxide defectiveness.
In complex oxide compounds with the structural typical disorder of the oxygen sublattice, in contrast to phases with impurity disordering, the number of vacancies in the oxygen sublattice may be considerably higher, therefore the high oxygen deficiency is able to provide a significant level of concentration of protons (and therefore, proton conductivity) [5]. Such features allow us to consider these compounds as a distinct class of proton conductors and suggest the need to devise new ways to describe them. At the same time, a combination of properties, such as high concentrations of protons and high reversibility of the processes of hydration, gives ground to consider this class of proton conductors as a promising matrix for proton transport. 
In the present work we report a detailed study of the crystal structure of proton conductor $\mathrm{Ba}_{4} \mathrm{Ca}_{2} \mathrm{Nb}_{2} \mathrm{O}_{11}$ and set the preferred places of localization of pro- tons, and also developed a quasichemical approach to describe the processes of formation of proton defects.

\section{Experimental part}

The synthesis of the sample with a nominal composition of $\mathrm{Ba}_{4} \mathrm{Ca}_{2} \mathrm{Nb}_{2} \mathrm{O}_{11}$ was conducted by solid-phase synthesis from the pre-dried carbonates and niobium oxide at temperature endurances 800-1000-1200-1300 ${ }^{\circ} \mathrm{C}$ for $24 \mathrm{~h}$ with intermediate chafing. The hydrated samples were obtained by slow cooling $\left(1^{\circ} \mathrm{C} / \mathrm{min}\right)$ with $1000{ }^{\circ} \mathrm{C}$ to $150-200^{\circ} \mathrm{C}$ in the humid air $\left(\mathrm{pH}_{2} \mathrm{O}=2 \cdot 10^{-2} \mathrm{~atm}\right)$. The amount of absorbed water was controlled by the method of thermogravimetry.

The neutron diffraction studies were performed at the nuclear research reactor IVV-2M (Zarechny town, Sverdlovsk region) using diffractometer D-7A with a double monochromator. The first monocrystal is pyrolytic graphite with a reflective plane (002), the second is germanium, the reflection plane is 511 . The wavelength of monochromatic neutrons is $\lambda=1.5255 \AA$. Data were obtained at room temperature in the angular range $9-130{ }^{\circ} \mathrm{C}$ with a step of $0.05^{\circ} \mathrm{C}$ and angular resolution is $\Delta \mathrm{d} / \mathrm{d}=0.02 \%$. The refinement of crystal structure was carried out using full-profile analysis on Rietveld by using the software package FullProf [6].

\section{Results and discussion}

According to the results of local energy-dispersive $\mathrm{x}$-ray microanalysis it is established that the stoichiometry of the synthesized sample was maintained within 1 at. $\%$, there was a slight variation in the values of ratios of $\mathrm{Ba}: \mathrm{Ca}: \mathrm{Nb}$, the over-
The studies of surface morphology of the samples was performed by scanning electron microscope JEOL JSM-6390LA. For the quantitative determination of the elemental composition of the samples the energy dispersive microanalysis with energy dispersive console JEOL JED 2300 was carried out. The limit of detection at normal energies $(5-20 \mathrm{kV})$ was $\sim 0.5$ at. \%. The error of concentration measurement is $\pm 2 \%$. The management, monitoring and analysis of the received data were carried out using the software package Analysis Station JED series, Version 3.7.

The thermogravimetric studies were carried out in the heating process in the atmosphere of dry Ar in thermoanalyzer TG STA 409 PC (NETZSCH) included with unit quadrupole mass spectrometer QMS 403C Aëlos. The shooting of isothermal dependences of the mass from the partial pressure of water vapor was performed with stepwise change of humidity from $\mathrm{pH}_{2} \mathrm{O}=3 \cdot 10^{-5}$ atm to $\mathrm{pH}_{2} \mathrm{O}=2 \cdot 10^{-2}$ atm. Under each value of the activity of water vapor the system was maintained to a state of equilibrium within a few days.

all composition of the sample was characterized by a slight lack of Ca.

The study of the morphology of the powder sample did not reveal the presence of impurity phases, the homogene- 
ous distribution of metal components was observed.

The structure of the anhydrous sample $\mathrm{Ba}_{4} \mathrm{Ca}_{2} \mathrm{Nb}_{2} \mathrm{O}_{11}$ was investigated by using neutron diffraction. Fig. 1 shows experimental, calculated and differential profiles of neutronography.

It is established that the crystal structure $\mathrm{Ba}_{4} \mathrm{Ca}_{2} \mathrm{Nb}_{2} \mathrm{O}_{11}$ is described in the structural type of the double perovskite $\mathrm{A}_{2}\left(\mathrm{BB}^{\prime}\right) \mathrm{O}_{6}$, and is characterized by a cubic cell with space group $F m \overline{3} m$, which corresponds well with $\mathrm{x}$-ray diffraction stud-

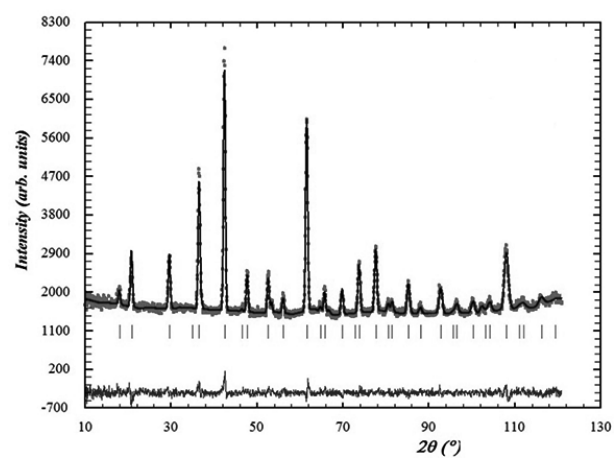

Fig. 1. Neutrongramma sample composition $\mathrm{Ba}_{4} \mathrm{Ca}_{2} \mathrm{Nb}_{2} \mathrm{O}_{11}$, shows the experimental (points), calculated (line) and difference (bottom) data and the angular position of the reflexes for cubic phases (strokes) ies carried out previously [7]. For four formula units $\mathrm{A}_{2}\left(\mathrm{BB}^{\prime}\right) \mathrm{O}_{6}$ the following distribution of hydrogen atoms in the positions is characterized: $8 \mathrm{c}$-crystallographic positions are filled with cations of barium (A-sublattice), the cations B-sublattice (niobium and calcium) occupy two crystallographically nonequivalent positions $4 a$ and $4 b$, the oxygen takes position $24 e$. The main results of calculations are presented in table 1. According to the data about the coordinates of the atoms and the unit cell parameters the interatomic distances were calculated (table 2). The structure is built from connected by vertices different octahedra $\mathrm{NbO}_{6}$ and $\mathrm{CaO}_{6}$ formed by orderly arranged atoms of niobium and calcium and is oxygen-deficient, which is confirmed by the partial filling of oxygen positions. The location of oxygen vacancies is statistical, as the predominant places of their localization have not been identified.

The next step was the study of the structure of the sample $\mathrm{Ba}_{4} \mathrm{Ca}_{2} \mathrm{Nb}_{2} \mathrm{O}_{11}$ in hydrated form. The degree of hydration was established according to data of thermogravimetry, the overall composition is corresponded to the formula $\mathrm{Ba}_{4} \mathrm{Ca}_{2} \mathrm{Nb}_{2} \mathrm{O}_{11} \cdot 0.96 \mathrm{H}_{2} \mathrm{O}$.

Table 1

The coordinates and isotropic thermal parameters (B) atoms of the anhydrous sample $\mathrm{Ba}_{4} \mathrm{Ca}_{2} \mathrm{Nb}_{2} \mathrm{O}_{11}$

\begin{tabular}{|c|c|c|c|c|c|c|}
\hline \multirow{2}{*}{ atom } & \multirow{2}{*}{ position } & \multicolumn{3}{|c|}{ The coordinates of the atoms } & \multirow{2}{*}{$\begin{array}{l}\text { coefficient of } \\
\text { filling }\end{array}$} & \multirow{2}{*}{$\mathrm{B} \times 100, \AA^{2}$} \\
\hline & & $x$ & $y$ & $z$ & & \\
\hline $\mathrm{Nb}$ & $4 \mathrm{a}$ & 0 & 0 & 0 & 1.00 & $0.5(1)$ \\
\hline $\mathrm{Ca}$ & $4 \mathrm{~b}$ & 0 & 0 & 0.5 & $0.935(2)$ & $1.76(4)$ \\
\hline $\mathrm{Ba}$ & $8 \mathrm{c}$ & 0.25 & 0.25 & 0.25 & 1.00 & $1.59(9)$ \\
\hline $\mathrm{O}_{-5}$ & $24 \mathrm{e}$ & $0.2347(5)$ & $\begin{array}{c}0 \\
2-126\end{array}$ & $\begin{array}{c}0 \\
P\left(F^{2}\right)-3\end{array}$ & $0.917(5)$ & $2.54(8)$ \\
\hline
\end{tabular}

Characteristics of atoms:

Space group $F m \overline{3} m$, cubic symmetry, $\mathrm{Z}=4$

The unit cell parameters: $\mathrm{a}=b=c=8.4428(3) \AA ; \mathrm{a}=\mathrm{b}=\mathrm{g}=90^{\circ} ; \mathrm{V}=601.80(3) \AA^{3}$; X-ray density $5.47 \mathrm{~g} / \mathrm{cm}^{3}$ 
Table 2 Interatomic distances $(\AA)$ in the coordination polyhedra in the anhydrous sample

\begin{tabular}{c|c|c|c}
\multicolumn{4}{|c|}{$\mathrm{Ba}_{4} \mathrm{Ca}_{2} \mathrm{Nb}_{2} \mathrm{O}_{11}$} \\
$\begin{array}{c}\text { Interatomic } \\
\text { distances }\end{array}$ & $\mathrm{BaO}_{12}$ & $\mathrm{CaO}_{6}$ & $\mathrm{NbO}_{6}$ \\
\hline $\mathrm{M}-\mathrm{O}$ & 2.987 & 2.222 & 1.999 \\
\hline $\mathrm{O}-\mathrm{O}$ & & 3.142 & 2.827
\end{tabular}

Based on the data of neutron diffraction it was found that when hydrated niobate of barium-calcium the cell symmetry is reduced to monoclinic and can be described in the space group $\mathrm{P} 2_{1} / n$. Neutrongramma is presented in Fig. 2.

As a result of absorption of water is the filling of oxygen vacancies by oxygen atoms from the water molecules, respectively, the total content of oxygen in hydrated sample increases, as evidenced by the corresponding fill coefficients. Thus there is a distortion of the octahedra and the position of the oxygen atoms become non-equivalent. The data for the atomic coordinates and interatomic distances are in tables 3, 4. As can be seen, the distance from the atom of niobium up to four equatorial oxygen atoms is equal to $2.013 \AA$ and $2.115 \AA$, and to the axial atoms is $2.066 \AA$. In Ca-octahedron these distances are slightly larger, respectively, to the equatorial oxygen atoms is $2.226 \AA$ and $2.125 \AA$, and to the axial atoms is $2.254 \AA$.

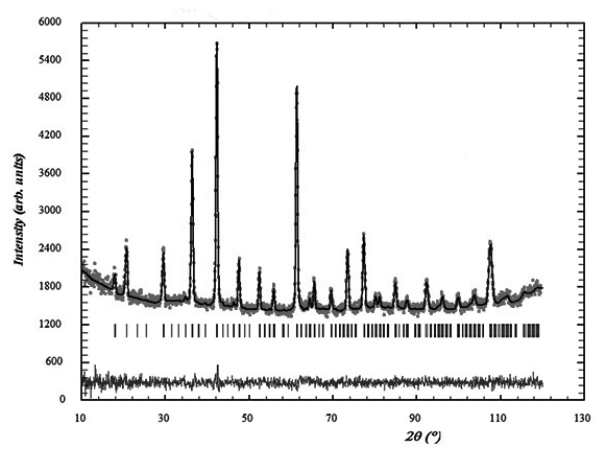

Fig. 2. Neutrongramma of sample $\mathrm{Ba}_{4} \mathrm{Ca}_{2} \mathrm{Nb}_{2} \mathrm{O}_{11} \cdot 0.96 \mathrm{H}_{2} \mathrm{O}$ shows the experimental (points), calculated (line) and difference (bottom) data and the angular position of the reflexes for monoclinic phase (strokes)

Table 3

The coordinates and isotropic thermal parameters (B) atoms in $\mathrm{Ba}_{4} \mathrm{Ca}_{2} \mathrm{Nb}_{2} \mathrm{O}_{11} \cdot 0.96 \mathrm{H}_{2} \mathrm{O}$ according to data of neutron

\begin{tabular}{c|c|c|c|c|c|c} 
Atom & \multirow{2}{*}{ Position } & \multicolumn{3}{|c|}{ The coordinates of the atom } & $\begin{array}{c}\text { Filling } \\
\text { (abs.ed) }\end{array}$ & $\mathrm{B} \times 100, \AA^{2}$ \\
\hline & & $x$ & $y$ & $z$ & & \\
\hline $\mathrm{Ba}$ & $4 \mathrm{e}$ & -0.01312 & -0.00354 & 0.7422 & 4.00 & $1.893(2)$ \\
$\mathrm{Nb}$ & $2 \mathrm{~d}$ & 0.50000 & 0.00000 & 0.00000 & 2.00 & $0.889(1)$ \\
\hline $\mathrm{Ca}$ & $2 \mathrm{c}$ & 0.50000 & 0.00000 & 0.50000 & $1.815(7)$ & $0.989(4)$ \\
\hline $\mathrm{O} 1$ & $4 \mathrm{e}$ & 0.24055 & 0.26523 & 0.49187 & $4.000(0)$ & $2.705(3)$ \\
\hline $\mathrm{O} 2$ & $4 \mathrm{e}$ & 0.24067 & -0.24146 & 0.49764 & $4.000(0)$ & $3.069(8)$ \\
\hline $\mathrm{O} 3$ & $4 \mathrm{e}$ & -0.02101 & 0.47958 & 0.73512 & $3.616(0)$ & $1.13(11)$ \\
$\mathrm{H} 1$ & $4 \mathrm{e}$ & 0.10214 & 0.47503 & 0.63517 & 0.764 & $1.13(11)$ \\
$\mathrm{H} 2$ & $4 \mathrm{e}$ & 0.27941 & 0.15590 & 0.20102 & 0.366 & $1.13(11)$ \\
$\mathrm{H} 3$ & $4 \mathrm{e}$ & 0.07867 & 0.19818 & 0.09212 & 0.727 & $1.13(11)$
\end{tabular}

$\mathrm{R}_{\text {wp }}=3.16 \% ; \mathrm{R}_{\mathrm{p}}=4.80 \% ; \mathrm{R}_{\mathrm{f}}=5.39 \% ; \chi^{2}=1.36$

Characteristics of atoms:

Space group $\mathrm{P} 2 / n$, monoclinic symmetry

The unit cell parameters: $a=5.9864(3) \AA ; ; a=g=90^{\circ} ; b=5.9964(0) \AA ; \quad b=89.838(15)^{\circ}$; $c=8.4958(2) \AA ; \quad V=304.97(3) \AA^{3}$; X-ray density of $5.42 \mathrm{~g} / \mathrm{cm}^{3}$ 
The position of the protons is described by three possible positions $\mathrm{H} 1, \mathrm{H} 2, \mathrm{H} 3$. Most of the protons ( $\mathrm{H} 1$ and $\mathrm{H} 2$ ) is localized on axial oxygen atoms $\mathrm{O} 3$, forming $\mathrm{OH}^{-}$-groups in which the distances oxygen-hydrogen are as follows: $1.125 \AA$, $1.219 \AA$ (Fig. 3). The H3 protons are localized at the equatorial oxygen atoms, shifting slightly above and below the equatorial plane and forming $\mathrm{OH}^{-}$-groups with a sufficiently large connection lengths of $1.37 \AA$ (bond $\mathrm{O} 2-\mathrm{H} 3$ ). The positions of the $\mathrm{H} 2$ have a small filling, the main part of protons is distributed on the positions $\mathrm{H} 1$ and $\mathrm{H} 3$, which have approximately the same population (table 4).

Interatomic distance $(\AA)$ in the structure

Table 4 $\mathrm{Ba}_{4} \mathrm{Ca}_{2} \mathrm{Nb}_{2} \mathrm{O}_{11} \cdot 0.96 \mathrm{H}_{2} \mathrm{O}$

\begin{tabular}{|c|c|c|c|}
\hline $\begin{array}{l}\text { polyhe- } \\
\text { dron }\end{array}$ & $\mathrm{M}-\mathrm{O} 1$ & $\mathrm{M}-\mathrm{O} 2$ & $\mathrm{M}-\mathrm{O} 3$ \\
\hline $\mathrm{CaO}_{6}$ & $\begin{array}{c}2.226 \\
(\times 2)\end{array}$ & $2.124(\times 2)$ & $\begin{array}{c}2.254 \\
(\times 2)\end{array}$ \\
\hline $\mathrm{NbO}_{6}$ & $2.012(\times 2)$ & $2.115(\times 2)$ & $\begin{array}{c}2.006 \\
(\times 2)\end{array}$ \\
\hline $\mathrm{BaO}_{12}$ & $\begin{array}{l}3.068 \\
3.109 \\
2.885 \\
2.945 \\
\end{array}$ & $\begin{array}{l}2.941 \\
3.164 \\
2.861 \\
3.032 \\
\end{array}$ & $\begin{array}{l}3.098 \\
2.899 \\
2.798 \\
3.203 \\
\end{array}$ \\
\hline$d \mathrm{O}-\mathrm{H}$ & & & \\
\hline $\mathrm{O} 3-\mathrm{H} 1$ & \multicolumn{3}{|c|}{1.125} \\
\hline $\mathrm{O} 3-\mathrm{H} 2$ & \multicolumn{3}{|c|}{1.219} \\
\hline $\mathrm{O} 2-\mathrm{H} 3$ & \multicolumn{3}{|c|}{1.371} \\
\hline
\end{tabular}

Based on the data for fill factors, it can be concluded that there is a good correlation with the results of energy dispersive $\mathrm{x}$-ray microanalysis on quantitative composition phase. The general formula can be written as $\mathrm{H}_{1.86} \mathrm{Ba}_{4} \mathrm{Ca}_{1.82} \mathrm{Nb}_{2} \mathrm{O}_{4} \mathrm{O}_{4} \mathrm{O}_{3.62}$ or by highlighting hydroxo group $\mathrm{Ba}_{4} \mathrm{Ca}_{1.82}(\mathrm{OH})_{1.86} \mathrm{Nb}_{2} \mathrm{O}_{7.14}$.

The hydration processes were studied by the method of thermogravimetry under the variations of temperature and partial pressure of water vapor in the gas phase $\mathrm{pH}_{2} \mathrm{O}$ (Fig. 4, 5).

On TG curves (Fig. 4) there has been a dramatic change in mass of the sample at a temperature of $400-450{ }^{\circ} \mathrm{C}$, which

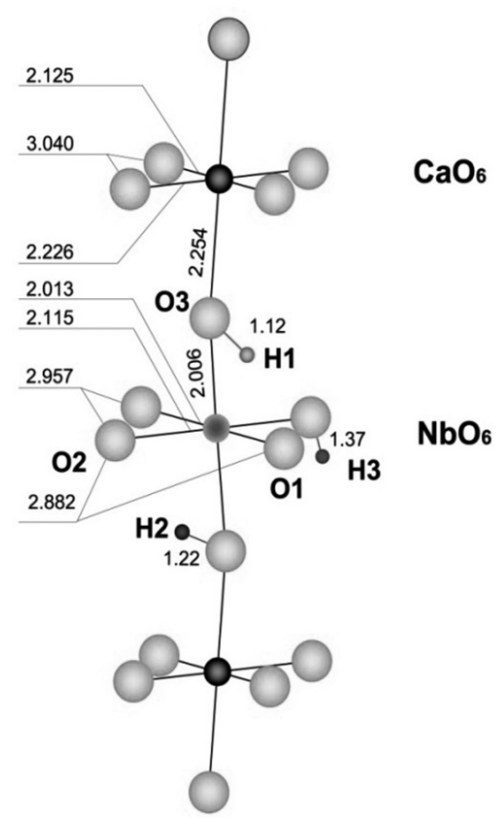

Fig. 3. The fragment structure of the sample $\mathrm{Ba}_{4} \mathrm{Ca}_{2} \mathrm{Nb}_{2} \mathrm{O}_{11} \cdot 0.96 \mathrm{H}_{2} \mathrm{O}$; shows the main interatomic distances $(\AA)$ in the $\mathrm{NbO}_{6}$ octahedra and $\mathrm{CaO}_{6}$ and the positions of the protons $\mathrm{H} 1, \mathrm{H} 2, \mathrm{H} 3$

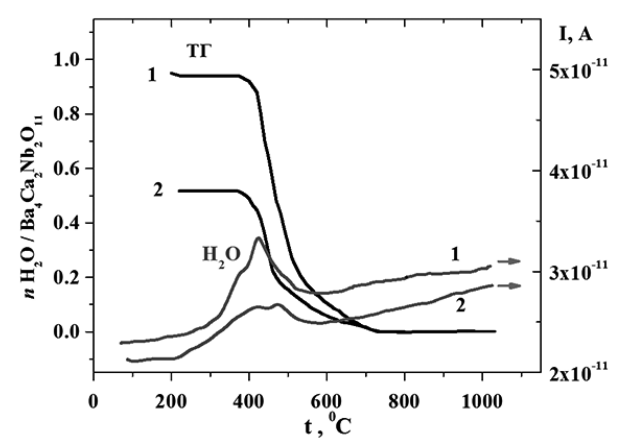

Fig. 4. TG curves and mass spectrum (ion current) water allocations in (1) $\mathrm{Ba}_{4} \mathrm{Ca}_{2} \mathrm{Nb}_{2} \mathrm{O}_{11} \cdot 0.95 \mathrm{H}_{2} \mathrm{O}$ and (2) $\mathrm{Ba}_{4} \mathrm{Ca}_{2} \mathrm{Nb}_{2} \mathrm{O}_{11} \cdot 0.50 \mathrm{H}_{2} \mathrm{O}$ (partial hydration) 


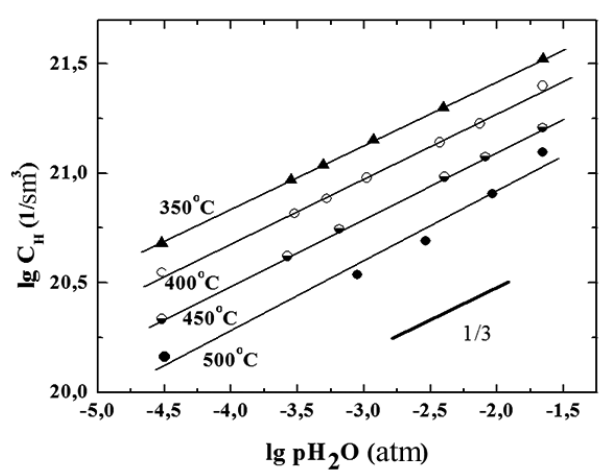

Fig. 5. The dependence of the concentration of proton defects in the structure $\mathrm{Ba}_{4} \mathrm{Ca}_{2} \mathrm{Nb}_{2} \mathrm{O}_{11} \cdot n \mathrm{H}_{2} \mathrm{O}$ from partial pressure of water vapor

removed the main amount of water $(0.65$ mole), next there were more monotonous change in mass of up to $700{ }^{\circ} \mathrm{C}$.

The mass spectrum characterizing the allocation of water, for extremely hydrated composition $\mathrm{Ba}_{4} \mathrm{Ca}_{2} \mathrm{Nb}_{2} \mathrm{O}_{11} \cdot 0.96 \mathrm{H}_{2} \mathrm{O}$ is presented by a peak in the temperature range $250-550{ }^{\circ} \mathrm{C}$, its complex type indicates the superposition of several signals and reflects the presence of three overlapping effects. The mass spectrum of the allocation of water of partially hydrated sample $\mathrm{Ba}_{4} \mathrm{Ca}_{2} \mathrm{Nb}_{2} \mathrm{O}_{11} \cdot 0.5 \mathrm{H}_{2} \mathrm{O}$ shows the redistribution of the peak intensities, primarily a decrease in intensity of low temperature peak of the allocation of water.

The crystallographic non-equivalence of the $\mathrm{OH}^{-}$-groups is manifested in their different thermal stability. The isolated $\mathrm{OH}^{-}$-groups, that are remoted from the adjacent oxygen atoms at distances comparable to the size of the octahedron, are the most thermally resistant, and this fact reflects the greatest strength of bond $\mathrm{O}-\mathrm{H}$.

The dependences of the concentration of protons from the partial pressure of water vapor $\lg \mathrm{C}_{\mathrm{H}}=f\left(\operatorname{lgpH}_{2} \mathrm{O}\right)$ is presented in
Fig. 5. As you can see, in the area of investigated temperatures range $300-500{ }^{\circ} \mathrm{C}$ and $\mathrm{pH}_{2} \mathrm{O}=3 \cdot 10^{-5} \div 2 \cdot 10^{-2}$ atm there is an increase in the concentration of protons with increasing $\mathrm{pH}_{2} \mathrm{O}$, the dependences in a logarithmic scale are characterized by a linear function with a slope of $1 / 3$.

To describe the process of dissociative dissolution of water vapour in a matrix of complex oxide we used the quasichemical approach, which allows to demonstrate the dependence of the concentration of proton defects from atmospheric humidity. The quasichemical description of the process of water absorption is sufficient detaily described for perovskite-like phases, in which oxygen vacancies are set acceptor doping. In these views, the formation of proton defects is considered as the appearance of the proton localized on oxygen, so it is represented as a particle $\mathrm{OH}^{-}$, which occupies the anionic site $(\mathrm{OH})_{\mathrm{O}}^{\bullet}$. The corresponding equation of quasi-chemical reactions is as follows:

$$
\mathrm{V}_{\mathrm{O}}^{\bullet \bullet}+\mathrm{H}_{2} \mathrm{O}_{\text {газ }}+\mathrm{O}_{\mathrm{O}}^{\times} \Leftrightarrow 2(\mathrm{OH})_{\mathrm{O}}^{\bullet} \text {, }
$$

where $\mathrm{V}_{\mathrm{O}}^{\bullet \bullet}$ - the oxygen vacancy, $\mathrm{O}_{\mathrm{O}}^{\times}$the oxygen atom in the regular position, $(\mathrm{OH})_{\mathrm{O}}^{\circ}$ - hydroxyl group in the oxygen sublattice with an effective positive charge.

Accordingly, the concentration of proton defects in the structure of the oxide increases with increasing partial pressure of water vapor as $\left[\mathrm{OH}_{\mathrm{O}}^{-}\right] \propto \mathrm{pH}_{2} \mathrm{O}^{1 / 2}(T=$ const), where $\left[\mathrm{OH}_{\mathrm{O}}^{\bullet}\right]$ is the concentration of the defect. Usually the experimentally observed functional dependence $\lg \mathrm{C}_{\mathrm{H}}=$ $f\left(\operatorname{lgpH}_{2} \mathrm{O}\right)\left(\mathrm{C}_{\mathrm{H}}\right.$ - volume concentration of proton defects) for acceptare doped perovskites $\mathrm{ABO}_{3-\delta}$ is characterized by the slope $\mathrm{dlg} \mathrm{C}_{\mathrm{H}} / \mathrm{d} \lg \mathrm{pH}_{2} \mathrm{O} \approx 1 / 2$ [8].

For phases with the structural disordering of the oxygen vacancies should be considered as neutral defects (vacant 
oxygen positions), therefore the water implementation process should be described otherwise. However, the emergence of neutral defects in quasi-chemical reactions creates uncertainty, since the concentration of this neutral defect cannot be made in the condition of electroneutrality (CEN), and therefore it is impossible to establish its functional relationship with the concentrations of other defects. To avoid this situation it is usually proposed to take into account the equilibrium of the type:

$$
\mathrm{O}_{\mathrm{O}}^{\times}+\mathrm{V}_{\mathrm{O}}^{\times} \Leftrightarrow \mathrm{V}_{\mathrm{O}}^{\bullet \bullet}+\mathrm{O}_{\mathrm{v}_{\mathrm{o}}}^{\prime \prime},
$$

where the formation of doubly ionized oxygen vacancies $\mathrm{V}_{\mathrm{O}}^{\bullet \bullet}$ occurs as a result of the migration of lattice oxygen on the place of structural vacancy, while the oxygen atom becomes formally effective negative charge corresponding to the charge of an atom in interstitial positions $\mathrm{O}_{\mathrm{v}_{\mathrm{o}}}^{\prime \prime}$ [9]. Thus, the implementation process of the water is reduced to the equation (1).

The experimental results obtained in the present work on studing of dependency $\lg \mathrm{C}_{\mathrm{H}}=f\left(\operatorname{lgp} \mathrm{H}_{2} \mathrm{O}\right)$ for $\mathrm{Ba}_{4} \mathrm{Ca}_{2} \mathrm{Nb}_{2} \mathrm{O}_{11}$ with structural disordering showed that a previously proposed model cannot describe the observed dependence with a slope of $1 / 3$. Therefore, the following cases of dissociative dissolution of water in the matrix of the complex oxide with the structural disordering of the oxygen sublattice are considered below. If we consider the process of introducing water with the participation of oxygen vacancies as a neutral defect, it can be assumed that oxygen from water molecules is embedded in the place of structural vacancy, and the protons are placed at regular oxygen points:

$$
\mathrm{H}_{2} \mathrm{O}+2 \mathrm{O}_{\mathrm{O}}^{\times}+\mathrm{V}_{\mathrm{O}}^{\times} \Leftrightarrow 2 \mathrm{OH}_{\mathrm{O}}^{\bullet}+\mathrm{O}_{\mathrm{v}_{\mathrm{o}}}^{\prime \prime}
$$

The condition of electroneutrality (CEN) can be written as: $2\left[\mathrm{O}_{\mathrm{V}_{\mathrm{o}}}^{\prime \prime}\right]=\left[\mathrm{OH}_{\mathrm{O}}^{\cdot}\right]$. The electronic defects are excluded from the CEN, because it determines the conditions for dominance of atomic disordering. In addition, there is an additional relationship between the concentrations of neutral defects and oxygen vacancies. If we assume that initially, in the complex oxide the volumetric concentration of oxygen vacancies is characterized by some constant value, then the introduction of water it decreases as: $A-\left[\mathrm{O}_{\mathrm{V}_{\mathrm{o}}}^{\prime \prime}\right]=\left[\mathrm{V}_{\mathrm{O}}^{\times}\right]$.

The equilibrium constant of reaction (3) can be written as follows:

$$
K=\frac{\left[\mathrm{OH}_{\mathrm{O}}^{\cdot}\right]^{2} \cdot\left[\mathrm{O}_{\mathrm{v}_{\mathrm{o}}}^{\prime \prime}\right]}{\mathrm{pH}_{2} \mathrm{O} \cdot\left[\mathrm{V}_{\mathrm{O}}^{\times}\right]}=\frac{\left[\mathrm{OH}_{\mathrm{o}}^{*}\right]^{2} \cdot\left[\mathrm{O}_{\mathrm{V}_{\mathrm{o}}}^{\prime \prime}\right]}{\mathrm{pH}_{2} \mathrm{O} \cdot\left(\mathrm{A}-\left[\mathrm{O}_{\mathrm{v}_{\mathrm{o}}}^{\prime \prime}\right]\right)}
$$

For analysis of the dependence of concentration of defects at a variation $\mathrm{pH}_{2} \mathrm{O}$ ( $T=$ const $)$ we consider the conditions of approximation, corresponding to the three possible cases.

1) The low $\mathrm{pH}_{2} \mathrm{O}$

$\left[\mathrm{V}_{\mathrm{O}}^{\times}\right] \approx A ;>>\left[\mathrm{O}_{\mathrm{V}_{\mathrm{O}}}^{\prime \prime}\right],\left[\mathrm{OH}_{\mathrm{O}}^{\bullet}\right]$

2) The middle $\mathrm{pH}_{2} \mathrm{O}$

$2\left[\mathrm{O}_{\mathrm{V}_{\mathrm{O}}}^{\prime \prime}\right]=\left[\mathrm{OH}_{\mathrm{O}}^{\bullet}\right]>>\left[\mathrm{V}_{\mathrm{O}}^{\times}\right]$

Since $\left[\mathrm{O}_{\mathrm{V}_{\mathrm{o}}}^{\prime \prime}\right]<A$, then the concentration of defects will be:

$$
\begin{aligned}
& {\left[\mathrm{O}_{\mathrm{V}_{0}}^{\prime \prime}\right]<A,=(2 \mathrm{AK})^{1 / 3} \cdot\left(\mathrm{pH}_{2} \mathrm{O}\right)^{1 / 3}} \\
& {\left[\mathrm{O}_{\mathrm{V}_{0}}^{\prime \prime}\right]=(A K / 4)^{1 / 3} \cdot\left(\mathrm{pH}_{2} \mathrm{O}\right)^{1 / 3}} \\
& {\left[\mathrm{~V}_{\mathrm{O}}^{\times}\right]=A-(A K / 4)^{1 / 3} \cdot\left(\mathrm{pH}_{2} \mathrm{O}\right)^{1 / 3}}
\end{aligned}
$$

That is, the concentration of dominant defects will be proportional $\mathrm{pH}_{2} \mathrm{O}^{1 / 3}$.

3) The high $\mathrm{pH}_{2} \mathrm{O}$

In the case of complete filling of oxygen vacancies as a result of the implementation of the water we have: $2\left[\mathrm{O}_{\mathrm{v}_{\mathrm{o}}}^{\prime \prime}\right]=\left[\mathrm{OH}_{\mathrm{O}}^{*}\right]=2 A,>>\left[\mathrm{V}_{\mathrm{O}}^{\times}\right]$. That is, the concentration of dominant defects do not depend on $\mathrm{pH}_{2} \mathrm{O}$

Fig. $6 a$ presents the dependence of concentration of defects from $\mathrm{pH}_{2} \mathrm{O}$ in logarithmic coordinates. 
Thus, it can be expected that at low temperatures the concentration of proton defects will increase with increasing $\mathrm{pH}_{2} \mathrm{O}$ and in logarithmic coordinates it will have a slope of $1 / 3$. In experiments on study of conductivity as a function $\mathrm{pH}_{2} \mathrm{O}$, additionally taking that the mobility of the protons is much higher than the mobility of oxygen vacancies, in the simplest case, we should also expect the increase in the total conductivity as a function $\mathrm{pH}_{2} \mathrm{O}^{1 / 3}$.

The presented calculations for structural models of the oxygen vacancies show a contrast to the case of the introduction of water in complex oxides with impurity disordering. It should say that the equation (3) describing the penetration of water into structurally disordered complex oxides is not only. The appearance of oxygen on the place of structural vacancy as the defect with a negative charge $\mathrm{O}_{\mathrm{v}_{\mathrm{o}}}^{\prime \prime}$ creates conditions the preferential localization of the proton on the oxygen. Therefore, in the framework of the quasichemical formalism, this process can be written as follows:

$$
\mathrm{H}_{2} \mathrm{O}+\mathrm{O}_{\mathrm{O}}^{\times}+\mathrm{V}_{\mathrm{O}}^{\times} \Leftrightarrow \mathrm{OH}_{\mathrm{O}}^{\bullet}+\mathrm{OH}_{\mathrm{V}_{\mathrm{o}}}^{\prime}
$$

As can be seen, the formation of two types of proton defects with different charges takes place: localization of the proton on the oxygen, standing in a regu- lar position, leads to the appearance of the defect $\mathrm{OH}_{\mathrm{O}}^{\bullet}$, and on the oxygen coming from water molecules leads to the appearance $\mathrm{OH}_{\mathrm{v}_{\mathrm{o}}}^{\prime}$. The seeming contradiction related to the appearance of proton defects of opposite sign occurs because in the quasichemical description the defect is attributed to an effective charge which is determined as a differential value relative to the charge of the corresponding structural element in an ideal lattice, which is taken for zero. This writing means that the position of the protons is energetically different.

The possibility of reaction of proton exchange between lattice oxygen ions and oxygen ions, which has taken structural vacancy can be presented as follows:

$\mathrm{OH}_{\mathrm{O}}^{\bullet}+\mathrm{O}_{\mathrm{v}_{\mathrm{o}}}^{\prime \prime} \Leftrightarrow \mathrm{O}_{\mathrm{O}}^{\times}+\mathrm{OH}_{\mathrm{v}_{\mathrm{o}}}^{\prime}$.

We write equilibrium constants for reactions (5) and (6):

$$
K=\frac{\left[\mathrm{OH}_{\mathrm{O}}^{\bullet}\right] \cdot\left[\mathrm{OH}_{\mathrm{V}_{\mathrm{o}}^{\prime}}^{\prime}\right]}{\mathrm{pH}_{2} \mathrm{O} \cdot\left[\mathrm{V}_{\mathrm{O}}^{\times}\right]}=\frac{\left[\mathrm{OH}_{\mathrm{O}}^{\bullet}\right]^{2} \cdot\left[\mathrm{O}_{\mathrm{V}_{\mathrm{o}}}^{\prime \prime}\right]}{\mathrm{pH}_{2} \mathrm{O} \cdot\left(\mathrm{A}-\left[\mathrm{O}_{\mathrm{V}_{\mathrm{o}}}^{\prime \prime}\right]\right)}
$$

The condition of electroneutrality can be written as: $2\left[\mathrm{O}_{\mathrm{V}_{\mathrm{o}}}^{\prime \prime}\right]+\left[\mathrm{OH}_{\mathrm{V}_{\mathrm{o}}}^{\prime}\right]=\left[\mathrm{OH}_{\mathrm{O}}^{\bullet}\right]$. An additional relationship between the concentrations of defects and structural oxygen vacancies can be represented as: $\left[\mathrm{V}_{\mathrm{O}}^{\times}\right]=\mathrm{A}-\left(\left[\mathrm{O}_{\mathrm{V}_{\mathrm{o}}}^{\prime \prime}\right]+1 / 2\left[\mathrm{OH}_{\mathrm{V}_{\mathrm{o}}}^{\prime}\right]\right)$.

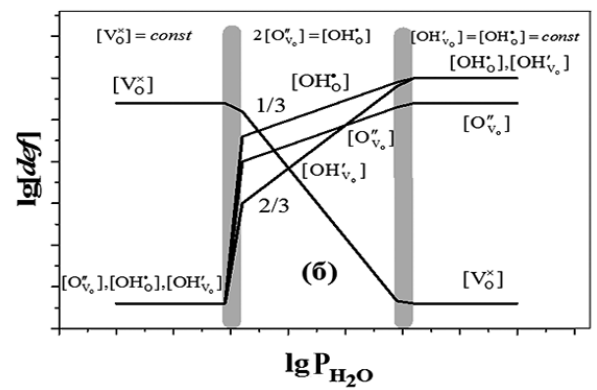

Fig. 6. The dependence of defects concentration from $\mathrm{pH}_{2} \mathrm{O}$ (double logarithmic coordinates) for models of defect formation in equations (3) and (5) 
The conditions of approximation will be represented by three possible cases ( $\mathrm{pH}_{2} \mathrm{O}=$ var, $\mathrm{T}=$ const).

1) The low $\mathrm{pH}_{2} \mathrm{O}$ $\left[\mathrm{V}_{\mathrm{O}}^{\times}\right] \approx \mathrm{A}>>\left[\mathrm{O}_{\mathrm{V}_{\mathrm{o}}}^{\prime \prime}\right],\left[\mathrm{OH}_{\mathrm{O}}^{\bullet}\right],\left[\mathrm{OH}_{\mathrm{V}_{\mathrm{o}}}^{\prime}\right]$.

2) The middle $\mathrm{pH}_{2} \mathrm{O}$

$2\left[\mathrm{O}_{\mathrm{V}_{\mathrm{o}}}^{\prime \prime}\right]=\left[\mathrm{OH}_{\mathrm{O}}^{\bullet}\right]>>\left[\mathrm{OH}_{\mathrm{d}}^{\prime}\right]$

$\left[\mathrm{OH}_{\mathrm{O}}^{\circ}\right] \sim\left(\mathrm{pH}_{2} \mathrm{O}\right)^{1 / 3}$

$\left[\mathrm{O}_{\mathrm{V}_{\mathrm{o}}}^{\prime \prime}\right] \sim\left(\mathrm{pH}_{2} \mathrm{O}\right)^{1 / 3}$

$\left[\mathrm{OH}_{\mathrm{V}_{\mathrm{o}}}^{\prime}\right] \sim\left(\mathrm{pH}_{2} \mathrm{O}\right)^{2 / 3}$.

3) The high $\mathrm{pH}_{2} \mathrm{O}$. In the case of complete filling of oxygen vacancies as a result of introduction of water we have: $\left[\mathrm{OH}_{\mathrm{V}_{\mathrm{O}}}^{\prime}\right]=\left[\mathrm{OH}_{\mathrm{O}}^{\bullet}\right] \approx 2 A$ That is, the concentration of dominant defects does not depend on $\mathrm{pH}_{2} \mathrm{O}$. The concentration $\left[\mathrm{V}_{\mathrm{O}}^{\times}\right]$is low, a $\left[\mathrm{O}_{\mathrm{V}_{\mathrm{o}}}^{\prime \prime}\right] \approx A$. Fig. $6 b$ shows the calculated dependences in logarithmic coordinates.

Comparing the diagrams, it is seen that in general both approaches give a similar situation: the bulk of experimental data of the dependence of the concentration of proton defects from $\mathrm{pH}_{2} \mathrm{O}$ in loga- rithmic coordinate will be described by a slope of $1 / 3$ with a gradual withdrawal to the plateau at high partial pressures of water vapor.

Thus, the differences in the quasichemical approaches of the description of oxygen vacancies formally define the different functional dependence of the concentration of resulting proton defects from $\mathrm{pH}_{2} \mathrm{O}$. In the case of doubly ionized oxygen vacancies $\mathrm{V}_{\mathrm{O}}^{\bullet \bullet}$, when the process of interaction with water is reduced to a quasi-chemical equation (1), the concentration of proton defects in the structure of the oxide increases with increasing water vapor activity under the law $\left[\mathrm{OH}_{\mathrm{O}}^{\bullet}\right] \propto \mathrm{pH}_{2} \mathrm{O}^{1 / 2}$. For phases with neutral defects, the concentration of protons is proportional to $\mathrm{pH}_{2} \mathrm{O}^{1 / 3}$.

The authors thank k-phm.n. Voronin, Vladimir Ivanovich (IPM UB RAS) for helping in data processing for structural analysis.

1. Norby T. Ceramic proton and mixed proton-electron conductors in membranes for energy conversion applications. J. of Chem. Eng. of Japan. 2007;40:1166-1171.

2. Reijers R., Haije W. Literature review on high temperature proton conducting materials. Energy research Centre of the Netherlands. 2008. ECN-E-08-091.

3. Phair J. W., Badwal S. P. S. Review of proton conductors for hydrogen separation. Ionics. 2006;12:103-115.

4. Kreuer K. D. Proton-conducting oxides. Annu. Rev. Mater. Res. 2003;33:333-359.

5. Animitsa I. Perovskites: Structure, Properties and Uses. Ed. Maxim Borowski, Nova Science Publishers. Inc. New York, 2010, pp. 501-524.

6. Rodriguez-Carvajal J. Recent Developments of the Program FULLPROF. Commission on Powder Diffraction, (IUCr). Newsletter. 2001;26:12-19.

7. Animitsa I., Neiman A., Kochetova N., Melekh B., Sharafutdinov A. Proton and Oxygen-ion conductivity of $\mathrm{Ba}_{4} \mathrm{Ca}_{2} \mathrm{Nb}_{2} \mathrm{O}_{11}$. Solid State Ionics. 2003;162-163:63-71.

8. Pal'gyev S. F. High-temperature proton solid electrolytes. Ekaterinburg, UB RAS, $1998.82 \mathrm{p}$.

9. Smyth D. M. Defects and order in perovskite-related oxides. Ann. Rev. Mater. Sci. 1985;5:329-357. 
И. Е. Анимица, Н. А. Кочетова

Уральский федеральный университет 620002, г. Екатеринбург, ул. Мира, 19 тел.: (343) 261-74-70

E-mail:irina.animitsa@urfu.ru

\section{Кристаллическая структура и дефектность перовскитоподобного протонного проводника $\mathrm{Ba}_{4} \mathrm{Ca}_{2} \mathrm{Nb}_{2} \mathrm{O}_{11}$}

Методом нейтронографии изучена кристаллическая структура сложного оксида $\mathrm{Ba}_{4} \mathrm{Ca}_{2} \mathrm{Nb}_{2} \mathrm{O}_{11}$ в безводной и гидратированной формах, установлены предпочтительные места локализации протонов. Изучен процесс гидратации при варьировании температуры и парциального давления паров воды. Установлено, что кристаллографическая неэквивалентность $\mathrm{OH}^{-}$-групп в структуре обуславливает их различную термическую устойчивость. Предложен квазихимический подход, описывающий образование протонных дефектов в оксидах со структурным разупорядочением.

\footnotetext{
Ключевые слова: нейтронограмма; квазихимический подход; высокотемператуные протонные проводники (ВТПП).

(C) Анимица И. Е., Кочетова Н. А., 2016
}

\section{Введение}

Протонные проводники находят широкое применение в качестве компонентов электрохимических устройств, таких как газовые сенсоры, электролизеры, мембраны топливных элементов и др. [1-3]. Класс высокотемпературных протонных проводников (ВТПП) представлен сложнооксидными соединениями со структурой перовскита $\mathrm{ABO}_{3}$ или производной от нее. В ВТПП водород не является составной частью химической формулы, его появление в структуре сложного оксида обеспечивается равновесием с $\mathrm{H}_{2} \mathrm{O} / \mathrm{H}_{2}$-содержащей атмосферой и описывается как процесс диссоциативного растворения паров воды/ водорода [4]. Поскольку наличие вакансий кислорода является основным фактором, ответственным за появление протонных дефектов, то величина протонной проводимости определяется дефектностью сложного оксида.

В сложнооксидных соединениях со структурной разупорядоченностью кислородной подрешетки, в отличие от фаз с примесным разупорядочением, число вакансий в кислородной подрешетке может быть существенно выше, поэтому высокий кислородный дефицит способен обеспечить значимый уровень концентрации протонов (и, соответственно, протонной проводимости) [5]. Именно такие особен- 
ности позволяют рассматривать эти соединения как отдельный класс протонных проводников и предполагают необходимость разработки новых способов их описания. В то же время сочетание таких свойств, как высокие концентрации протонов и высокая обратимость процессов гидратации, дает основание рассматривать этот класс протонных проводников как

\section{Экспериментальная часть}

Синтез образца номинального состава $\mathrm{Ba}_{4} \mathrm{Ca}_{2} \mathrm{Nb}_{2} \mathrm{O}_{11}$ проводился методом твердофазного синтеза из предварительно осушенных карбонатов и оксида ниобия при температурных выдержках 800-1000-1200-1300 ${ }^{\circ} \mathrm{C}$ по 24 ч. с промежуточными перетираниями. Гидратированные образцы были получены медленным охлаждением ( $1{ }^{\circ} \mathrm{C} /$ мин) с $1000{ }^{\circ} \mathrm{C}$ до $150-200{ }^{\circ} \mathrm{C}$ в атмосфере влажного воздуха $\left(\mathrm{pH}_{2} \mathrm{O}=\right.$ $=2 \cdot 10^{-2}$ атм). Количество поглощенной воды контролировалось методом термогравиметрии.

Нейтронографические исследования проводили на исследовательском атомном реакторе ИВВ-2М (г. Заречный Свердловской обл.) при использовании дифрактометра Д-7А с двойным монохроматором. Первый монокристалл - пиролитический графит с отражающей плоскостью (002), второй германий, плоскость отражения (511). Длина волны монохроматических нейтронов $\lambda=1,5255 \AA$ А. Данные были получены при комнатной температуре в угловом интервале $9-130{ }^{\circ} \mathrm{C}$ с шагом $0,05{ }^{\circ} \mathrm{C}$ и угловым разрешением $\Delta \mathrm{d} / \mathrm{d}=0,02 \%$. Уточнение кристаллической структуры проводилось методом полнопрофильного анализа по Рит- перспективные матрицы для протонного транспорта.

В настоящей работе проведено детальное исследование кристаллической структуры протонного проводника $\mathrm{Ba}_{4} \mathrm{Ca}_{2} \mathrm{Nb}_{2} \mathrm{O}_{11}$ и установлены предпочтительные места локализации протонов, а также разработан квазихимический подход описания процессов образования протонных дефектов.

вельду с использованием программного пакета FullProf [6].

Исследования морфологии поверхности образцов проводили на сканирующем электронном микроскопе JEOL JSM-6390LA. Для количественного определения элементного состава образцов был проведен энергодисперсионный микроанализ с помощью энергодисперсионной приставки JEOL JED 2300. Предел детектирования при обычных энергиях (5-20 кВ) составил 0,5 ат.\%, ошибка измерения концентрации $\pm 2 \%$. Управление, контроль работы и анализ полученных данных осуществляли с использованием программного пакета Analysis Station, JED series, Version 3.7.

Термогравиметрические исследования проводились в процессе нагрева в атмосфере сухого Ar на термоанализаторе TG STA 409 PC (Netzsch) в комплекте с блоком квадрупольного массспектрометра QMS 403C Aëlos. Съемку изотермических зависимостей массы от парциального давления паров воды осуществляли при стадийной смене влажности от $\mathrm{pH}_{2} \mathrm{O}=3 \cdot 10^{-5}$ атм до $\mathrm{pH}_{2} \mathrm{O}=2 \cdot 10^{-2}$ атм. При каждом значении активности паров воды система выдерживалась до состояния равновесия в течение нескольких суток. 


\section{Результаты и обсуждение}

По результатам локального энергодисперсионного рентгеновского микроанализа установлено, что стехиометрия синтезированного образца сохранялась в пределах 1 ат. \%, наблюдался незначительный разброс в значениях соотношений $\mathrm{Ba}: \mathrm{Ca}: \mathrm{Nb}$, общий состав образца характеризовался незначительным недостатком Са. Исследование морфологии порошкового образца не выявило наличия примесных фаз, наблюдалось гомогенное распределение металлических компонентов.

Структура безводного образца $\mathrm{Ba}_{4} \mathrm{Ca}_{2} \mathrm{Nb}_{2} \mathrm{O}_{11}$ была исследована методом нейтронной дифракции. На рис. 1 представлены экспериментальный, рассчитанный и разностный профили нейтронограммы.

Установлено, что кристаллическая структура $\mathrm{Ba}_{4} \mathrm{Ca}_{2} \mathrm{Nb}_{2} \mathrm{O}_{11}$ описывается в структурном типе двойного перовскита $\mathrm{A}_{2}\left(\mathrm{BB}^{\prime}\right) \mathrm{O}_{6}$ и характеризуется кубической ячейкой с пространственной группой $F m \overline{3} m$, что хорошо соотносится с рентгенографическими исследованиями, проведенными ранее [7]. Для четырех формульных единиц $\mathrm{A}_{2}\left(\mathrm{BB}^{\prime}\right) \mathrm{O}_{6}$ характерно следующее распределение атомов по позициям: 8c-кристаллографические позиции заполняются катионами бария (А-подрешетка), катионы В-подрешетки (ниобий и кальций) заселяют две кристаллографически неэквивалентные позиции - $4 a$ и $4 b$, кислород занимает позиции 24e. Основные результаты расчетов представлены в табл. 1. По данным о координатах атомов и параметрах элементарной ячейки были рассчитаны межатомные расстояния (табл. 2). Структура построена из

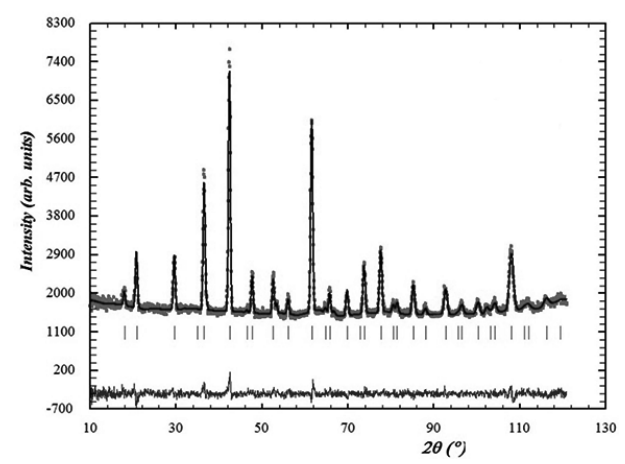

Рис. 1. Нейтронограмма образца состава $\mathrm{Ba}_{4} \mathrm{Ca}_{2} \mathrm{Nb}_{2} \mathrm{O}_{11}$, показаны экспериментальные (точки), расчетные (линия), разностные (внизу) данные и угловые положения рефлексов для кубической фазы (штрихи)

Таблица 1

Координаты и изотропные тепловые параметры (В) атомов безводного образца $\mathrm{Ba}_{4} \mathrm{Ca}_{2} \mathrm{Nb}_{2} \mathrm{O}_{11}$

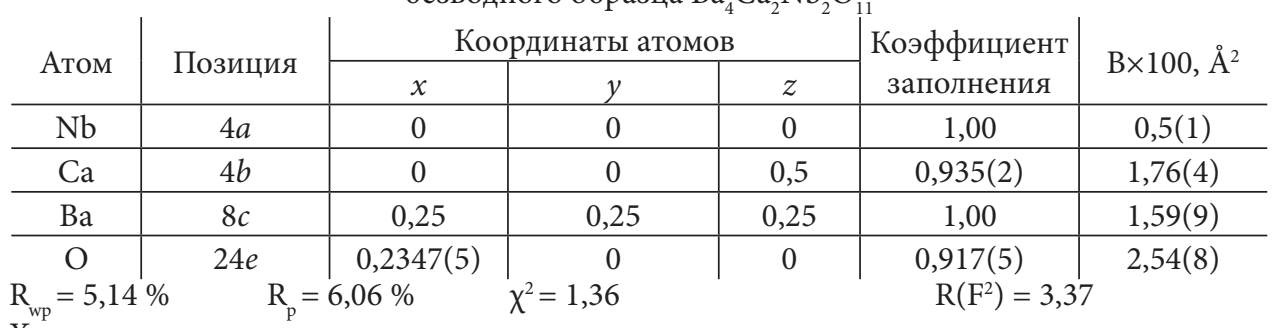

Характеристики атомов:

Пространственная группа $F m \overline{3} m$, кубическая симметрия, $Z=4$.

Параметры элементарной ячейки: $a=b=c=8,4428(3) \AA ; a=b=g=90^{\circ}$; V = 601,80(3) $\AA^{3}$.

Рентгеновская плотность $-5,47$ г/см 
связанных вершинами разноразмерных октаэдров $\mathrm{NbO}_{6}$ и $\mathrm{CaO}_{6}$, образованных упорядоченно расположенными атомами ниобия и кальция, и является кислород-дефицитной, что подтверждается частичным заполнением позиций кислорода. Расположение вакансий кислорода является статистическим, так как преимущественных мест их локализации не выявлено.

На основе данных нейтронной дифракции было установлено, что при гидратации ниобата бария-кальция симметрия ячейки понижается до моноклинной и может быть описана в пространственной группе $\mathrm{P} 2 / n$. Нейтронограмма представлена на рис. 2.

Следующим этапом работы было исследование структуры образца $\mathrm{Ba}_{4} \mathrm{Ca}_{2} \mathrm{Nb}_{2} \mathrm{O}_{11}$ в гидратированной форме. Степень гидратации была установлена по данным термогравиметрии, общий состав соответствовал формуле $\mathrm{Ba}_{4} \mathrm{Ca}_{2} \mathrm{Nb}_{2} \mathrm{O}_{11} \cdot 0,96 \mathrm{H}_{2} \mathrm{O}$.

$\mathrm{B}$ результате поглощения воды происходит заполнение кислородных вакансий атомами кислорода от молекул воды, соответственно, общее содержание кислорода в гидратированном образце увеличивается, что подтверждается соответствующими коэффициентами заполнения. При этом происходит искажение октаэдров, и позиции атомов кислорода становятся неэквивалентными. Данные по координатам атомов и межатомным расстояниям - в табл. 3, 4. Как видно, расстояния от атома ниобия до четырех экваториальных атомов кислорода равно 2,013 $\AA$ и 2,115 , а до аксиальных - 2,066 А․ В Са-октаэдре эти расстояния немного больше, соответственно, до экваториальных атомов кислорода - 2,226 А̊ и 2,125 и до аксиальных - 2,254.

Положение протонов описывается тремя возможными позициями $\mathrm{H} 1$, H2, Н3. Бо́льшая часть протонов (H1 и Н2) локализуется на аксиальных атомах кислорода $\mathrm{O}_{3}$, образуя $\mathrm{OH}^{-}$группы, в которых расстояния кислород-водород распределяются следующим образом: 1,125 ̊, 1,219 (рис. 3). Протоны Н3 локализуются на экваториальных атомах кислорода, смещаясь немного выше и ниже экваториальной плоскости и образуя $\mathrm{OH}^{-}$-группы с достаточно большими длинами связи $1,37 \AA$ (связь $\mathrm{O}_{2}-$ $\mathrm{H}_{3}$ ). Позиции $\mathrm{H} 2$ имеют небольшое заполнение, основная часть протонов распределяется по позициям $\mathrm{H} 1$ и $\mathrm{H} 3$,

Таблица 2

Межатомные расстояния (А)

в координационных полиэдрах

в безводном образце $\mathrm{Ba}_{4} \mathrm{Ca}_{2} \mathrm{Nb}_{2} \mathrm{O}_{11}$

\begin{tabular}{c|c|c|c}
$\begin{array}{c}\text { Межатомные } \\
\text { расстояния }\end{array}$ & $\mathrm{BaO}_{12}$ & $\mathrm{CaO}_{6}$ & $\mathrm{NbO}_{6}$ \\
\hline $\mathrm{M}-\mathrm{O}$ & 2,987 & 2,222 & 1,999 \\
\hline $\mathrm{O}-\mathrm{O}$ & & 3,142 & 2,827
\end{tabular}

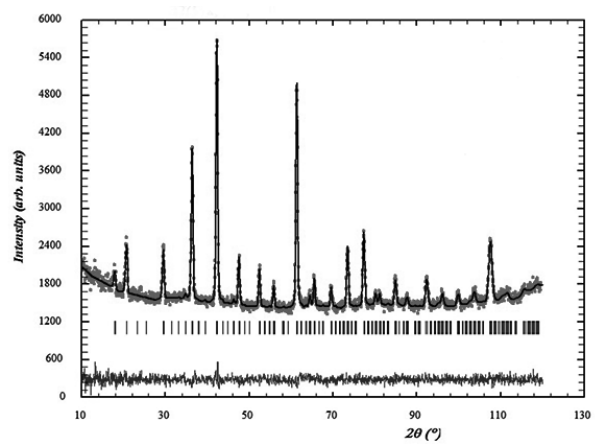

Рис. 2. Нейтронограмма образца $\mathrm{Ba}_{4} \mathrm{Ca}_{2} \mathrm{Nb}_{2} \mathrm{O}_{11} \cdot 0.96 \mathrm{H}_{2} \mathrm{O}$; показаны экспериментальные (точки), расчетные (линия), разностные (внизу) данные и угловые положения рефлексов для моноклинной фазы (штрихи) 
Таблица 3

Координаты и изотропные тепловые параметры (B) атомов в $\mathrm{Ba}_{4} \mathrm{Ca}_{2} \mathrm{Nb}_{2} \mathrm{O}_{11} \cdot 0,96 \mathrm{H}_{2} \mathrm{O}$ по данным нейтронной дифракции

\begin{tabular}{c|c|c|c|c|c|c}
\multirow{2}{*}{ Атом } & \multirow{2}{*}{ Позиция } & \multicolumn{3}{|c|}{ Координаты атома } & \multirow{2}{*}{$\begin{array}{c}\text { Заполнение } \\
\text { (абс. ед.) }\end{array}$} & \multirow{2}{*}{$\mathrm{B} \times 100, \AA^{2}$} \\
\cline { 3 - 5 } & & $x$ & $y$ & $z$ & 4,00 & $1,893(2)$ \\
$\mathrm{Ba}$ & $4 e$ & $-0,01312$ & $-0,00354$ & 0,7422 & 2,00 & $0,889(1)$ \\
\hline $\mathrm{Nb}$ & $2 d$ & 0,50000 & 0,00000 & 0,00000 & $0,815(7)$ & $0,989(4)$ \\
\hline $\mathrm{Ca}$ & $2 \mathrm{c}$ & 0,50000 & 0,00000 & 0,50000 & 1,000 & $2,705(3)$ \\
\hline $\mathrm{O} 1$ & $4 e$ & 0,24055 & 0,26523 & 0,49187 & $4,000(0)$ & $3,069(8)$ \\
\hline $\mathrm{O} 2$ & $4 e$ & 0,24067 & $-0,24146$ & 0,49764 & $4,000(0)$ & $1,13(11)$ \\
\hline $\mathrm{O} 3$ & $4 e$ & $-0,02101$ & 0,47958 & 0,73512 & $3,616(0)$ & $1,13(11)$ \\
$\mathrm{H} 1$ & $4 e$ & 0,10214 & 0,47503 & 0,63517 & 0,764 & $1,13(11)$ \\
$\mathrm{H} 2$ & $4 e$ & 0,27941 & 0,15590 & 0,20102 & 0,366 & $1,13(11)$ \\
$\mathrm{H} 3$ & $4 e$ & 0,07867 & 0,19818 & 0,09212 & 0,727 &
\end{tabular}

$\mathrm{R}_{\mathrm{wp}}=3,16 \% \quad \mathrm{R}_{\mathrm{p}}=4,80 \% \quad \mathrm{R}_{\mathrm{f}}=5,39 \% \quad \chi^{2}=1,36$

Характеристики атомов:

Пространственная группа $\mathrm{P} 2 / 1 / n$, моноклинная симметрия.

Параметры элементарной ячейки: $a=5,9864(3) \AA ; ; a=g=90 ; b=5,9964(0) \AA$; $b=89,838(15)^{\circ} ; c=8,4958(2) \AA ; \mathrm{V}=304,97(3) \AA^{3}$.

Рентгеновская плотность $-5,42$ г/ $\mathrm{cm}^{3}$.

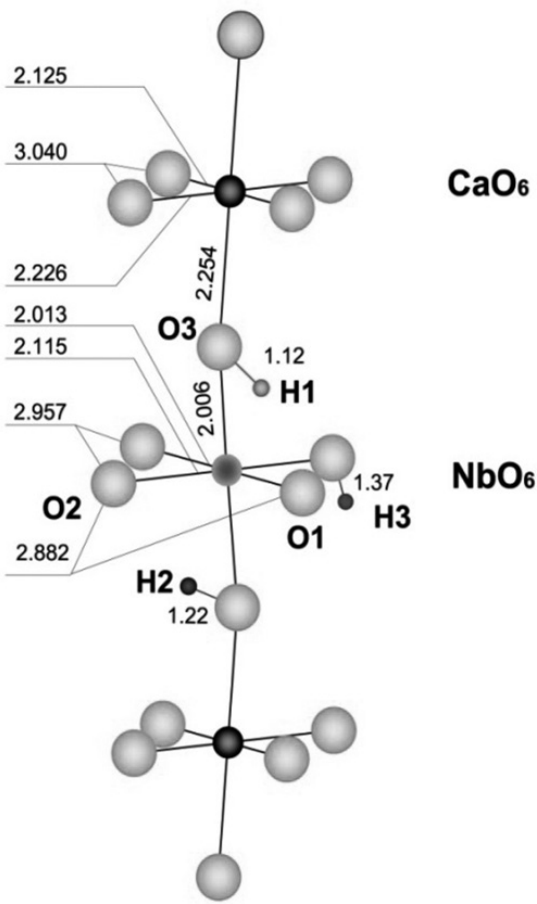

Рис. 3. Фрагмент структуры образца

$\mathrm{Ba}_{4} \mathrm{Ca}_{2} \mathrm{Nb}_{2} \mathrm{O}_{11} \cdot 0,96 \mathrm{H}_{2} \mathrm{O}$; показаны основные межатомные расстояния $(\AA)$ в октаэдрах $\mathrm{NbO}_{6}$ и $\mathrm{CaO}_{6}$ и позиции протонов Н1, H2, $\mathrm{H} 3$ которые имеют примерно одинаковое заполнение (табл. 4).

Исходя из данных по коэффициентам заполнения, можно заключить, что наблюдается хорошая корреляция с результатами энергодисперсионного рентгеновского микроанализа по количественному составу фазы. Общая формула может быть записана как $\mathrm{H}_{1,86} \mathrm{Ba}_{4} \mathrm{Ca}_{1,82} \mathrm{Nb}_{2} \mathrm{O}_{4} \mathrm{O}_{4} \mathrm{O}_{3,62}$ или, выделяя гидроксогруппу, $\mathrm{Ba}_{4} \mathrm{Ca}_{1,82}(\mathrm{OH})_{1.86} \mathrm{Nb}_{2} \mathrm{O}_{7,14}$.

Таблица 4

Межатомные расстояния $(\AA)$ в структуре $\mathrm{Ba}_{4} \mathrm{Ca}_{2} \mathrm{Nb}_{2} \mathrm{O}_{11} \cdot 0,96 \mathrm{H}_{2} \mathrm{O}$

\begin{tabular}{c|c|c|c} 
полиэдр & $\mathrm{M}-\mathrm{O} 1$ & $\mathrm{M}-\mathrm{O} 2$ & $\mathrm{M}-\mathrm{O} 3$ \\
\hline $\mathrm{CaO}_{6}$ & $2,226(\times 2)$ & $2,124(\times 2)$ & $2,254(\times 2)$ \\
\hline $\mathrm{NbO}_{6}$ & $2,012(\times 2)$ & $2,115(\times 2)$ & $2,006(\times 2)$ \\
\hline $\mathrm{BaO}_{12}$ & 3,068 & 2,941 & 3,098 \\
& 3,109 & 3,164 & 2,899 \\
& 2,885 & 2,861 & 2,798 \\
& 2,945 & 3,032 & 3,203 \\
\hline $\boldsymbol{d}$ O-H & \multicolumn{3}{|c}{1,125} \\
\hline $\mathrm{O} 3-\mathrm{H} 1$ & \multicolumn{3}{|c}{1,219} \\
\hline $\mathrm{O} 3-\mathrm{H} 2$ & \multicolumn{3}{|c}{}
\end{tabular}


Процессы гидратации изучались методом термогравиметрии при варьировании температуры и парциального давления паров воды в газовой фазе $\mathrm{pH}_{2} \mathrm{O}$ (рис. 4, 5).

На ТГ-кривых (рис. 4) наблюдается резкое изменение массы образца при температуре $400-450{ }^{\circ} \mathrm{C}$, в результате которого удалялось основное количество воды (0,65 моль), далее происходило монотонное изменение массы до $700{ }^{\circ} \mathrm{C}$.

Масс-спектр, характеризующий выделение воды, для предельно гидратированного состава $\mathrm{Ba}_{4} \mathrm{Ca}_{2} \mathrm{Nb}_{2} \mathrm{O}_{11} \times$ $\times 0,96 \mathrm{H}_{2} \mathrm{O}$, представлен пиком в области температур $250-550{ }^{\circ} \mathrm{C}$, его сложный вид свидетельствует о наложении нескольких сигналов, причем хорошо прослеживается наличие трех перекрывающихся эффектов. Масс-спектр выделения воды частично гидратированного образца $\mathrm{Ba}_{4} \mathrm{Ca}_{2} \mathrm{Nb}_{2} \mathrm{O}_{11} \cdot 0,5 \mathrm{H}_{2} \mathrm{O}$ демонстрирует перераспределение интенсивности пиков, в первую очередь наблюдается уменьшение интенсивности низкотемпературного пика выделения воды.

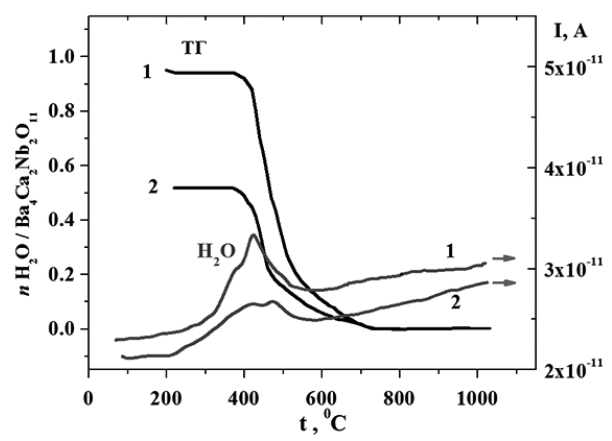

Рис. 4. ТГ-кривые и масс-спектр (ионный ток) выделения воды в (1) $\mathrm{Ba}_{4} \mathrm{Ca}_{2} \mathrm{Nb}_{2} \mathrm{O}_{11} \times$ $\times 0,95 \mathrm{H}_{2} \mathrm{O}$ и (2) $\mathrm{Ba}_{4} \mathrm{Ca}_{2} \mathrm{Nb}_{2} \mathrm{O}_{11} \cdot 0,50 \mathrm{H}_{2} \mathrm{O}$ (частичная гидратация)
То есть кристаллографическая неэквивалентность $\mathrm{OH}^{-}$-групп проявляется в их различной термической стойкости. Изолированные $\mathrm{OH}^{-}$-группы, то есть удаленные от соседних атомов кислорода на расстояния, сопоставимые с размерами октаэдра, являются наиболее термически стойкими, и это обстоятельство отражает наибольшую прочность связи О-Н.

Зависимости концентрации протонов от парциального давления паров воды представлены нарис. 5. Какможно видеть, в области исследованных температур 300-500 ${ }^{\circ} \mathrm{C}$ и р $\mathrm{H}_{2} \mathrm{O}=3 \cdot 10^{-5} \div$ $\div 2 \cdot 10^{-2}$ атм наблюдается увеличение концентрации протонов с увеличением $\mathrm{pH}_{2} \mathrm{O}$, зависимости в логарифмических координатах характеризуются линейной функцией с наклоном 1/3.

Для описания процесса диссоциативного растворения паров воды в матрице сложного оксида нами использован квазихимический подход, который позволяет наглядно продемонстрировать зависимость концентрации протонных дефектов от влажности атмосферы. Квазихимическое

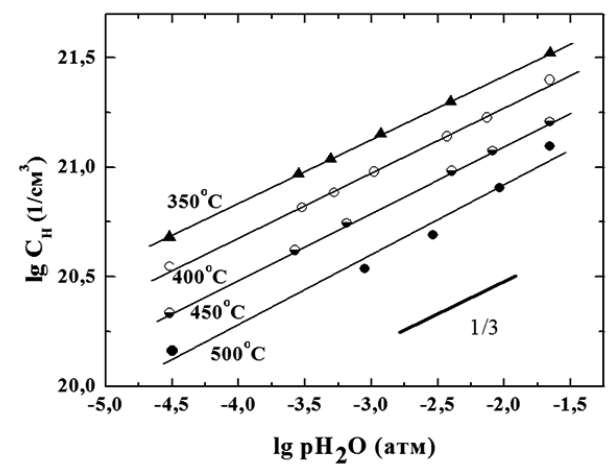

Рис. 5. Зависимость концентрации протонных дефектов в структуре $\mathrm{Ba}_{4} \mathrm{Ca}_{2} \mathrm{Nb}_{2} \mathrm{O}_{11} \times n \mathrm{H}_{2} \mathrm{O}$ от парциального давления паров воды 
описание процессов поглощения воды достаточно подробно описано для перовскитоподобных фаз, в которых вакансии кислорода задаются акцепторным допированием. В рамках этих представлений, образование протонных дефектов рассматривается как появление протона, локализованного на ионе кислорода, поэтому его представляют как частицу $\mathrm{OH}^{-}$, занимающую анионный узел - $(\mathrm{OH})_{\mathrm{O}}^{\bullet}$. Соответствующее уравнение квазихимической реакции следующее:

$$
\mathrm{V}_{\mathrm{O}}^{\bullet \bullet}+\mathrm{H}_{2} \mathrm{O}_{\text {газ }}+\mathrm{O}_{\mathrm{O}}^{\times} \Leftrightarrow 2(\mathrm{OH})_{\mathrm{O}}^{\bullet},
$$

где $\mathrm{V}_{\mathrm{O}}^{\bullet \bullet}$ - вакансия кислорода, $\mathrm{O}_{\mathrm{O}}^{\times}$атом кислорода в регулярной позиции, $(\mathrm{OH})_{\mathrm{O}}^{\bullet}$ - гидроксильная группа в подрешетке кислорода с эффективным положительным зарядом.

Соответственно, концентрация протонных дефектов в структуре оксида возрастает с увеличением парциального давления паров воды как $\left[\mathrm{OH}_{\mathrm{O}}^{\bullet}\right] \propto \mathrm{pH}_{2} \mathrm{O}^{1 / 2} \quad(T=$ const $)$, где $\left[\mathrm{OH}_{\mathrm{O}}^{\bullet}\right]$ - концентрация дефекта. Обычно экспериментально наблюдаемая функциональная зависимость $\lg \mathrm{C}_{\mathrm{H}}=f\left(\operatorname{lgp} \mathrm{H}_{2} \mathrm{O}\right)\left(\mathrm{C}_{\mathrm{H}}-\right.$ объемная концентрация протонных дефектов) для акцепторно допированных перовскитов $\mathrm{ABO}_{3-\delta}$ характеризуется наклоном $\mathrm{d} \lg \mathrm{C}_{\mathrm{H}} / \mathrm{d} \lg \mathrm{pH}_{2} \mathrm{O} \approx 1 / 2$ [8].

Для фаз со структурным разупорядочением вакансии кислорода следует рассматривать как нейтральные дефекты (незанятые кислородные позиции), поэтому процесс внедрения воды следует описывать иначе. Однако появление нейтральных дефектов в квазихимических реакциях создает неопределенность, поскольку концентрация такого нейтрального дефекта не может быть внесена в условие элек- тронейтральности (УЭН), и поэтому нельзя установить ее функциональную связь с концентрациями других дефектов. Чтобы избежать такой ситуации обычно предлагается учитывать равновесие типа:

$$
\mathrm{O}_{\mathrm{O}}^{\times}+\mathrm{V}_{\mathrm{O}}^{\times} \Leftrightarrow \mathrm{V}_{\mathrm{O}}^{\bullet \bullet}+\mathrm{O}_{\mathrm{V}_{\mathrm{o}}}^{\prime \prime},
$$

где образование двукратно ионизированной вакансии кислорода происходит в результате миграции решеточного кислорода на место структурной вакансии, при этом атом кислорода формально приобретает эффективный отрицательный заряд, соответствующий заряду атома в межузельной позиции [9]. Таким образом, процесс внедрения воды сводится к уравнению (1).

Экспериментальные результаты, полученные в настоящей работе по изучению зависимостей для $\mathrm{Ba}_{4} \mathrm{Ca}_{2} \mathrm{Nb}_{2} \mathrm{O}_{11}$ со структурным разупорядочением, показали, что предложенная ранее модель не может описать наблюдаемую зависимость с наклоном 1/3. Поэтому ниже рассмотрены случаи диссоциативного растворения воды в матрице сложного оксида со структурным разупорядочением подрешетки кислорода.

Если рассматривать процесс внедрения воды с участием вакансии кислорода как нейтрального дефекта, то можно предположить, что кислород от молекулы воды встраивается на место структурной вакансии, а протоны размещаются на регулярных узлах кислорода:

$$
\mathrm{H}_{2} \mathrm{O}+2 \mathrm{O}_{\mathrm{O}}^{\times}+\mathrm{V}_{\mathrm{O}}^{\times} \Leftrightarrow 2 \mathrm{OH}_{\mathrm{O}}^{\bullet}+\mathrm{O}_{\mathrm{v}_{\mathrm{o}}}^{\prime \prime} \text {. }
$$

Условие электронейтральности (УЭН) можно записать как: $2\left[\mathrm{O}_{\mathrm{v}_{\mathrm{O}}}^{\prime \prime}\right]=\left[\mathrm{OH}_{\mathrm{O}}^{\bullet}\right]$. Электронные дефекты исключены из УЭН, так как рассматриваются условия доминиро- 
вания атомного разупорядочения. Кроме того, существует дополнительная связь между концентрациями дефектов и нейтральными вакансиями кислорода. Если предположить, что изначально в сложном оксиде объемная концентрация вакансий кислорода характеризовалась некоторой постоянной величиной $\mathrm{A}$, то при внедрении воды она уменьшается как $A-\left[\mathrm{O}_{\mathrm{V}_{\mathrm{o}}}^{\prime \prime}\right]=\left[\mathrm{V}_{\mathrm{O}}^{\times}\right]$.

Константа равновесия реакции (3) запишется следующим образом:

$$
K=\frac{\left[\mathrm{OH}_{\mathrm{O}}^{\bullet}\right]^{2} \cdot\left[\mathrm{O}_{\mathrm{V}_{\mathrm{o}}}^{\prime \prime}\right]}{\mathrm{pH}_{2} \mathrm{O} \cdot\left[\mathrm{V}_{\mathrm{O}}^{\times}\right]}=\frac{\left[\mathrm{OH}_{\mathrm{O}}^{*}\right]^{2} \cdot\left[\mathrm{O}_{\mathrm{V}_{\mathrm{o}}}^{\prime \prime}\right]}{\mathrm{pH}_{2} \mathrm{O} \cdot\left(\mathrm{A}-\left[\mathrm{O}_{\mathrm{V}_{\mathrm{o}}}^{\prime \prime}\right]\right)} .
$$

Для анализа зависимости концентрации дефектов при вариации $\mathrm{pH}_{2} \mathrm{O}$ ( $T$ = const) рассмотрим условия аппроксимации, соответствующие трем возможным случаям.

\section{1) Низкие $\mathrm{pH}_{2} \mathrm{O}$ \\ $\left[\mathrm{V}_{\mathrm{O}}^{\times}\right] \approx A ;>>\left[\mathrm{O}_{\mathrm{V}_{\mathrm{O}}}^{\prime \prime}\right],\left[\mathrm{OH}_{\mathrm{O}}^{\bullet}\right]$.}

$$
\begin{aligned}
& \text { 2) Средние } \mathrm{pH}_{2} \mathrm{O} \\
& 2\left[\mathrm{O}_{\mathrm{V}_{\mathrm{O}}}^{\prime \prime}\right]=\left[\mathrm{OH}_{\mathrm{O}}^{\circ}\right]>>\left[\mathrm{V}_{\mathrm{O}}^{\times}\right] \text {. }
\end{aligned}
$$

Так как $<A$, то концентрации дефектов

$$
\begin{aligned}
& {\left[\mathrm{O}_{\mathrm{V}_{\mathrm{o}}^{\prime \prime}}^{\prime \prime}\right]<A,=(2 \mathrm{AK})^{1 / 3} \cdot\left(\mathrm{pH}_{2} \mathrm{O}\right)^{1 / 3}} \\
& {\left[\mathrm{O}_{\mathrm{V}_{\mathrm{o}}}^{\prime \prime}\right]=(A K / 4)^{1 / 3} \cdot\left(\mathrm{pH}_{2} \mathrm{O}\right)^{1 / 3}} \\
& {\left[\mathrm{~V}_{\mathrm{O}}^{\times}\right]=A-(A K / 4)^{1 / 3} \cdot\left(\mathrm{pH}_{2} \mathrm{O}\right)^{1 / 3} .}
\end{aligned}
$$

То есть концентрации доминирующих дефектов будут пропорциональны $\mathrm{pH}_{2} \mathrm{O}^{1 / 3}$.

\section{3) Высокие $\mathrm{pH}_{2} \mathrm{O}$.}

В случае полного заполнения вакансий кислорода в результате внедрения воды имеем: $2\left[\mathrm{O}_{\mathrm{V}_{\mathrm{o}}}^{\prime \prime}\right]=\left[\mathrm{OH}_{\mathrm{O}}^{\bullet}\right]=2 \mathrm{~A}$, $>\left[\mathrm{V}_{\mathrm{O}}^{\times}\right]$. То есть концентрации доминирующих дефектов не зависят от $\mathrm{pH}_{2} \mathrm{O}$.

На рис. 6, а представлены зависимости концентрации дефектов от $\mathrm{pH}_{2} \mathrm{O}$ в логарифмических координатах.

Таким образом, можно ожидать, что в невысоких температурах кон- центрация протонных дефектов будет возрастать с увеличением $\mathrm{pH}_{2} \mathrm{O}$ и в логарифмических координатах иметь наклон 1/3. В экспериментах по изучению проводимости как функции $\mathrm{pH}_{2} \mathrm{O}$, дополнительно учитывая, что подвижность протонов значительно превышает подвижность вакансий кислорода, в простейшем случае также следует ожидать увеличение общей проводимости как функции $\mathrm{pH}_{2} \mathrm{O}^{1 / 3}$.

Представленные расчеты для модели структурных вакансий кислорода демонстрируют отличие от случая внедрения воды в сложные оксиды с примесным разупорядочением.

Следует сказать, что уравнение (3), описывающее процесс внедрения воды в структурно-разупорядоченные сложные оксиды, не единственное. Появление кислорода на месте структурной вакансии, как дефекта с отрицательным зарядом $\mathrm{O}_{\mathrm{V}_{\mathrm{o}}}^{\prime \prime}$, создает предпосылки преимущественной локализации протона на этом кислороде. Поэтому в рамках квазихимического формализма данный процесс запишется следующим образом:

$$
\mathrm{H}_{2} \mathrm{O}+\mathrm{O}_{\mathrm{O}}^{\times}+\mathrm{V}_{\mathrm{O}}^{\times} \Leftrightarrow \mathrm{OH}_{\mathrm{O}}^{\bullet}+\mathrm{OH}_{\mathrm{v}_{\mathrm{o}}}^{\prime} .
$$

Как видно, происходит образование двух типов протонных дефектов с разными зарядами: локализация протона на кислороде, стоящем в регулярной позиции, приводит к появлению дефекта, а на кислороде, пришедшем от молекулы воды, - к появлению. Кажущееся противоречие, связанное с появлением протонных дефектов противоположного знака, возникает потому, что в квазихимическом описании дефекту приписывается эффективный заряд, определяющийся как разностное значение по отношению 


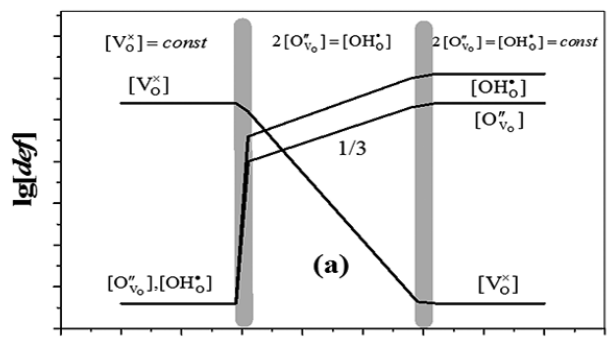

$a^{\lg \mathbf{P}_{\mathbf{H}_{\mathbf{2}} \mathbf{O}}}$

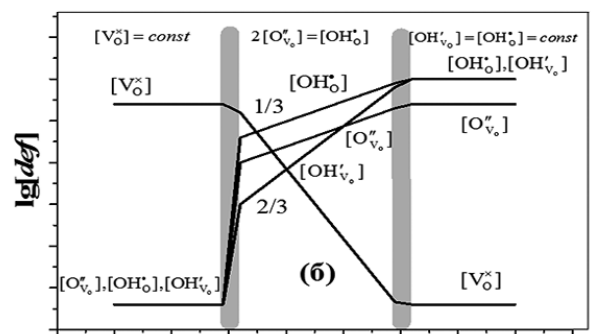

$\lg \mathbf{P}_{\mathrm{H}_{2} \mathrm{O}}$

6

Рис. 6. Зависимости концентрации дефектов от $\mathrm{pH}_{2} \mathrm{O}$ (двойные логарифмические координаты) для моделей дефектообразования по уравнениям (3) и (5)

к заряду соответствующего структурного элемента в идеальной решетке, которое принимают за нуль. Данная запись означает, что положение протонов энергетически различно.

Возможность протекания реакции протонного обмена между решеточными ионами кислорода и ионами кислорода, занявшими структурные вакансии, может быть представлена следующим образом:

$$
\mathrm{OH}_{\mathrm{O}}^{\bullet}+\mathrm{O}_{\mathrm{v}_{\mathrm{o}}}^{\prime \prime} \Leftrightarrow \mathrm{O}_{\mathrm{O}}^{\times}+\mathrm{OH}_{\mathrm{v}_{\mathrm{o}}}^{\prime} \text {. }
$$

Запишем константы равновесия для реакций (5) и (6):

$$
K=\frac{\left[\mathrm{OH}_{\mathrm{O}}^{\bullet}\right] \cdot\left[\mathrm{OH}_{\mathrm{V}_{\mathrm{o}}}^{\prime}\right]}{\mathrm{pH}_{2} \mathrm{O} \cdot\left[\mathrm{V}_{\mathrm{O}}^{\times}\right]}=\frac{\left[\mathrm{OH}_{\mathrm{O}}^{\bullet}\right]^{2} \cdot\left[\mathrm{O}_{\mathrm{V}_{\mathrm{o}}}^{\prime \prime}\right]}{\mathrm{pH}_{2} \mathrm{O} \cdot\left(\mathrm{A}-\left[\mathrm{O}_{\mathrm{V}_{\mathrm{o}}}^{\prime \prime}\right]\right)} .
$$

Условие электронейтральности запишетсякак: $2\left[\mathrm{O}_{\mathrm{V}_{\mathrm{o}}}^{\prime \prime}\right]+\left[\mathrm{OH}_{\mathrm{V}_{\mathrm{o}}}^{\prime}\right]=\left[\mathrm{OH}_{\mathrm{O}}^{\bullet}\right]$.

Дополнительная связь между концентрациями дефектов и структурными вакансиями кислорода может быть представлена в виде: $\left[\mathrm{V}_{\mathrm{O}}^{\times}\right]=\mathrm{A}-\left(\left[\mathrm{O}_{\mathrm{V}_{\mathrm{o}}}^{\prime \prime}\right]+1 / 2\left[\mathrm{OH}_{\mathrm{V}_{\mathrm{o}}}^{\prime}\right]\right)$.

Условия аппроксимации будут представлены тремя возможными случаями ( $\mathrm{pH}_{2} \mathrm{O}=\operatorname{var}, T=$ const $)$.

1) Низкие $\mathrm{pH}_{2} \mathrm{O}$

$\left[\mathrm{V}_{\mathrm{O}}^{\times}\right] \approx \mathrm{A}>>\left[\mathrm{O}_{\mathrm{V}_{\mathrm{o}}}^{\prime \prime}\right],\left[\mathrm{OH}_{\mathrm{O}}^{\bullet}\right],\left[\mathrm{OH}_{\mathrm{V}_{\mathrm{o}}}^{\prime}\right]$.

2) Средние $\mathrm{pH}_{2} \mathrm{O}$

$$
2\left[\mathrm{O}_{\mathrm{V}_{\mathrm{o}}}^{\prime \prime}\right]=\left[\mathrm{OH}_{\mathrm{O}}^{\circ}\right]>>\left[\mathrm{OH}_{\mathrm{d}}^{\prime}\right]
$$

$\left[\mathrm{OH}_{\mathrm{O}}^{\bullet}\right] \sim\left(\mathrm{pH}_{2} \mathrm{O}\right)^{1 / 3}$

$\left[\mathrm{O}_{\mathrm{V}_{\mathrm{o}}}^{\prime \prime}\right] \sim\left(\mathrm{pH}_{2} \mathrm{O}\right)^{1 / 3}$

$\left[\mathrm{OH}_{\mathrm{V}_{\mathrm{o}}}^{\prime}\right] \sim\left(\mathrm{pH}_{2} \mathrm{O}\right)^{2 / 3}$.

3) Высокие $\mathrm{pH}_{2} \mathrm{O}$. В случае полного заполнения вакансий кислорода в результате внедрения воды имеем, $\left[\mathrm{OH}_{\mathrm{V}_{\mathrm{o}}}^{\prime}\right]=\left[\mathrm{OH}_{\mathrm{O}}^{\bullet}\right] \approx 2 A$. То есть концентрация доминирующих дефектов не зависит от $\mathrm{pH}_{2} \mathrm{O}$. Концентрация $\left[\mathrm{V}_{\mathrm{O}}^{\times}\right]$мала, а $\left[\mathrm{O}_{\mathrm{v}_{\mathrm{o}}}^{\prime \prime}\right] \approx$ А. На рис. 6,6 представлены расчетные зависимости в логарифмических координатах.

Сравнивая представленные диаграммы, видно, что в общем случае оба подхода дают схожую ситуацию: основной массив экспериментальных данных зависимости концентрации протонных дефектов от $\mathrm{pH}_{2} \mathrm{O}$ в логарифмических координатах будет описываться наклоном 1/3 с постепенным выходом на плато в области высоких парциальных давлений паров воды.

Таким образом, различия в квазихимических подходах описания кислородных вакансий определяет формально различную функциональную зависимость концентрации образующихся протонных дефектов от $\mathrm{pH}_{2} \mathrm{O}$. В случае двукратно ионизированных вакансий кислорода $\mathrm{V}_{\mathrm{O}}^{\bullet}$, когда про- 
цесс взаимодействия с водой сводится к квазихимическому уравнению (1), концентрация протонных дефектов в структуре оксида возрастает с увеличением активности паров воды по закону $\left[\mathrm{OH}_{\mathrm{O}}^{\bullet}\right] \propto \mathrm{pH}_{2} \mathrm{O}^{1 / 2}$. Для фаз с ней- тральными дефектами концентрация протонов пропорциональна $\mathrm{pH}_{2} \mathrm{O}^{1 / 3}$. Авторы выражают благодарность к. ф.-м. н. Владимиру Ивановичу Воронину (ИФМ УрО РАН) за помощь при обработке данных по структурному анализу.

1. Norby T. Ceramic proton and mixed proton-electron conductors in membranes for energy conversion applications. J. of Chem. Eng. of Japan. 2007;40:1166-1171.

2. Reijers R., Haije W. Literature review on high temperature proton conducting materials. Energy research Centre of the Netherlands. 2008. ECN-E-08-091.

3. Phair J. W., S. Badwal P. S. Review of proton conductors for hydrogen separation. Ionics. 2006;12:103-115.

4. Kreuer K. D. Proton-conducting oxides. Annu. Rev. Mater. Res. 2003;33:333-359.

5. Animitsa I. in Perovskites: Structure, Properties and Uses. Ed. Maxim Borowski, Nova Science Publishers. Inc. New York, 2010. P. 501-524.

6. Rodriguez-Carvajal J.Recent Developments of the Program FULLPROF. Commission on Powder Diffraction, (IUCr). Newsletter. 2001;26:12-19.

7. Animitsa I., Neiman A., Kochetova N., Melekh B., Sharafutdinov A. Proton and Oxygen-ion conductivity of $\mathrm{Ba}_{4} \mathrm{Ca}_{2} \mathrm{Nb}_{2} \mathrm{O}_{11}$. Solid State Ionics. 2003;162-163:63-71.

8. Пальгуев С. Ф. Высокотемпературные протонные твердые электролиты. Екатеринбург: УрО РАН, 1998. 82 c.

9. Smyth D. M. Defects and order in perovskite-related oxides. Ann. Rev. Mater. Sci. 1985;5:329-357. 